High School. He studied medicine in the University of Glasgow and graduated M.B., Ch.B., in 1935 and M.D., with honours, in 1948. In 1936 he was appointed demonstrator in histology in the Department of Physiology at Glasgow; and in the same year became assistant to the professor of physiology, the late Prof. E. P. Cathcart. $\mathrm{He}$ became lecturer in physiology in 1940, and four years later was appointed to a similar post at King's College, University of London, where he became senior lecturer in 1948 and adviser of studies to the Medical Faculty in 1953. Prof. Knox has published work on the effect of exercise upon the heart-rate, based upon very accurate methods of counting. During the Second World War he worked with Dr. D. P. Cuthbertson on the effect of analeptics on fatigue. More recently, he has been interested in the electro-physiology of isolated muscle and its response to denervation. He has had very wide teaching experience both in Glasgow and in London.

\section{Philosophy at the University College of North Staffordshire: \\ Prof. A. G. N. Flew}

Mr. Antony Garrard Newton Flew, lecturer in philosophy in King's College, University of Aberdeen, has been appointed to the chair of philosophy in the University College of North Staffordshire in succession to Prof. W. B. Gallie. Prof. Flew was educated at Kingswood School, Bath, and was State Scholar in Japanese at the School of Oriental and African Studies in 1942, afterwards being attached to the Air Ministry in the Intelligence Section. He went to Oxford in 1946, taking a first in Greats in 1947, and was awarded the John Locke Scholarship in Mental Philosophy in 1948. He was then appointed lecturer in Christ Church, Oxford, before going to King's College, Aberdeen, in 1950. Prof. Flew has a considerable interest in adult education and has conducted many courses for the Workers' Educational Association and Service groups as well as broadcasting. His main studies lie in the notions of personal identity, survival and immortality, which have led him to a philosophical consideration of psycho-analysis and psychic phenomena. An enthusiastic mountaineer, Prof. Flew takes to his new post at North Staffordshire an energy and zeal which augur well for the rapidly developing school of philosophy in the College.

\section{Development of Canada during the Past Few Decades}

Addressing the Parliamentary and Scientific Committee on June 3, Dr. C. J. Mackenzie, president of the Atomic Energy Control Board, Canada, reviewed the fundamental political and economic changes which science and technology have made in Canada since 1918. He thinks that there is a substantial basis for Canada's prospects and prosperity. Since 1939, the population of Canada has increased from eleven to fifteen million, while the net income has doubled and government expenditure and foreign trade increased four-fold. Only 14 per cent of Canada's capital now comes from outside. Referring to the development of the National Research Council, formed in 1916, Dr. Mackenzie said that in 1939 it employed three hundred people, and there was a large reserve of well-trained research scientists. After the Second World War the Council undertook military and atomic encrgy research and now has six thousand employees. In agricultural research Canada spends
25-30 million dollars a year, or more per capita than any country in the world; Canada is now, and will remain, an industrial nation of the first rank. In reply to a question, Dr. Mackenzie said that since 1939 the National Research Council has lost only one senior man, and he knows of none who has left to go to the United States since 1946. In general, Canada has a surplus of research scientists ; but more people are going from Britain to Canada than are going from Canada to the United States. Attention may also be directed to the article on the conference on "Canada's To-morrow" on p. 212 of this issue.

\section{Commonwealth Conference on Human Problems} in Industry

At a recent meeting, at which H.R.H. The Duke of Edinburgh, patron of the Industrial Welfare Society, presided, it was decided that a Commonwealth and Empire Conference should be held in Britain (probably at Oxford) during July 1956. The purpose of the Conference will be to bring together representatives from the Commonwealth and Empire who would pool their knowledge and experience of the human problems of industry in their own countries. It is intended that the age of the delegates should normally be between twenty-five and forty. The Conference will deal with the human factors in industrialization as a whole : on one hand the personal factors of the health, satisfaction, effectiveness and well-being of those working in industry ; on the other, the social problems arising from the effects of industrialization on the lives of individuals, their families and communities. There is no suggestion that there should be consideration and discussion of the formal relationships between employers and trade unions, covering wages, conciliation and arbitration machinery, etc. Committees are to be set up to explore various aspects of the Conference, and a small steering committee, under the chairmanship of Sir Harold Hartley, was appointed to co-ordinate the work of the other committees. Further particulars can be obtained from the Industrial Welfare Society, 48 Bryanston Square, London, W.1.

\section{Division of Man-made Fibres, University of Leeds}

From October 1955 the Department of Textile Industries of the University of Leeds will consist of two Divisions-- the present Wool Division and a new Man-made Fibres Division. Good progress is being made with the new building for the Man-made Fibres Division, which is situated in University Road, opposite the present Department. The building will cost $£ 267,000$, towards which a donation of $£ 60,000$ has been made by Courtaulds, Ltd., and $£ 40,000$ by an anonymous donor. It consists of four floors, the first floor being the most important as this will contain the pilot plant for the production of all present-day types of man-made fibres, machines for processing various fibres, looms and knitting machinery. The ground floor will contain the dyeing, printing and finishing sections and also two humidity rooms. The sccond floor will consist mainly of two large teaching laboratories, and on the third floor will be two lecture rooms, capable of housing 84 and 150 people, respectively, as well as a well-lighted design studio. On each of the four floors there will also be a number of research laboratories. It is estimated that the equipment for the Division will cost about $£ 100,000$, part of which is being contributed by private industry. The donations include $£ 5,000$ from the Tootal Broadhurst Lee Company, 